2016, volume 5, issue 1

Papazov E., Mihaylova L. (2016). Accountancy-Based Sources of Information for Planning Purposes in SMEs. Copernican Journal of Finance \& Accounting, 5(1), 173-183. http://dx.doi.org/10.12775/ CJFA.2016.010

\author{
Emil Papazov* \\ University of National and World Economy, \\ Sofia \& University of Ruse, Bulgaria
}

LyUdMILA MihaYLOVA**

University of Ruse, Bulgaria

\title{
ACCOUNTANCY-BASED SOURCES OF INFORMATION FOR PLANNING PURPOSES IN SMES
}

Keywords: SMEs, Business Planning, Accountancy-Based Sources of Information.

J E L Classification: M21, M40.

Abstract: The present paper's research objective is to reveal the specifics and capabilities of the accountancy to serve as an information base for planning of the business of SMEs. In this regard, a research method (a survey) focusing on study of documentation in a number of Bulgarian SMEs has been carried out. Based on the results gained after the implementation of the research method, main sources of information for planning purposes in SMEs have been synthesized and evaluated. The main conclusions are that due to relatively high level of quality, actuality and availability, the accountancy-based data can constitute a major source of information for planning purposes in SMEs.

Date of submission: February 7, 2016; date of acceptance: May 8, 2016.

* Contact information: epapazov@gmail.com, Faculty of Business and Management, University of Ruse, 8 Studentska Str., Ruse-7017, Bulgaria, phone: +359879005316.

** Contact information: Imihaylova777@gmail.com, Faculty of Business and Management, University of Ruse, 8Studentska Str., Ruse-7017, Bulgaria, phone: +359879005325. 


\section{INTRODUCTION}

Planning is a complex process directed to preparing of managerial decisions for different types of organization. Notwithstanding the attempts to understate the role of plans for developing of complex systems, the dissemination of planning activities has recently grown up. At the same time, the methodology of planning has not altered in pace with the changes in the economic environment. Planning approaches, methods and techniques has not reflected the influence of certain realities typical for the modern business such as the increasing role and importance of small and medium-sized enterprises (SMEs) for the economic development. To the range of similar discrepancies can be added also those associated with the necessary information for practical application of appropriate planning tools (Papazov, Mihaylova 2014; Papazov, Mihaylova 2010; Simeonov, Lambovska 2012; Germanos, Pliota, Germanou 2013).

The accumulation and the usage of information stemming from different sources and the application of flexible planning methods, developed and / or adapted to the requirements and specifics of the SMEs are problems that are not solved yet fully. The mechanical transfer of approaches, methods and techniques from large companies to small and medium-sized enterprises cannot be recommended, as their application for planning purposes in SMEs does not render the expected results (Papazov 2014). A second major reason is the lack of connection or synchronization between planning and accountability in SMEs.

Having in mind the outlined range of issues, the emphasis of the present paper is put on the capabilities of company's accountancy to provide information needed for the business planning in SMEs. The purpose is, based on the results of a study in a number of Bulgarian SMEs, to synthesize the main sources of accountancy information that can be used for planning activity and to evaluate them in view of their actuality, quality and accessibility.

\section{RESEARCH PREMISES AND THE FOCUS OF THE RESEARCH PROCESS}

Corporate planning requires basic information sources. They are diverse by nature and by relevance with a company. In a paper written in compliance with quantitative limitations it is difficult to analyze all possible information sources. However, having in mind the research purpose, an attempt has been made to synthesize main information sources and to present some of their characteristics. 
A main difficulty comes out from the fact that some of the information needed for managerial decision making in SMEs is acquired through informal channels. Managers do often consultations with the company's personnel, talk with colleagues, customers and suppliers, and inform themselves from newspapers or specialized editions. Such sources of information are very useful, but they cannot always be used directly in the process of decision making, because they allow no proper integration with the overall planning construct.

Contemporary managers are experiencing a serious need to find formal ways to collect and process managerial information for planning purposes. The reason is that the amount of data increases in parallel with the size of the enterprise and the information flows become infinite and uncontrollable, if are not properly canalized. It is best to organize these flows in a system often called strategic enterprise information system (SEIP).

In the practice of company management a strategic enterprise information system is perceived not only as a formalized structure to provide strategic planning horizon. It serves as a starting point for implementation of other planned activities possessing tactical and operational characteristics. Additionally, SEIP is expected to dispose information about the past, present and future, albeit with a certain degree of conditionality. Thus, it should cover all processes in an organization, including events running beyond it, but connected with its activities. The most important thing is to provide information for making decisions to the right person, at the right time and the right place.

The providing of timely, accurate and detailed information for planning purposes, corresponding to the specifics of the SMEs, can be performed only by well-organized economic reporting in its diversity as operational, statistical and accounting. As a rule, for making rational strategic, tactical, and operational decisions the management needs a sufficient amount of reporting information with a respective quality. For the different types of managerial decisions the necessity of such information is not in equal proportions.

Practically, it is difficult to accurately measure the amount of the reporting information needed for planning purposes in a SME. The often emerging imbalances appear in form of shortage or surplus of information. It is necessary to look for an optimal ratio between the maximum and the minimum of the reporting information volume needed, which will greatly improve the process of the corporate planning.

The qualitative aspect of the reporting information is connected with its usefulness, i. e. with the possibility to contribute to the working out of a par- 
ticular managerial decision. Thus, according to the needs in making management decisions, accountancy information can be detailed to varying degrees. For example, strategic decisions are slightly differentiated and are based on generalized information about markets, products, resources and technologies, while operating decisions are highly differentiated and are based on detailed information with precise parameters for revenues, fixed costs, variable costs, etc. (Papazov, Mihaylova 2010; Peršić, Bakija, Vlašić 2015; Ciemleja, Lāce 2009; Kocmanová, Simberova 2014; Raulinajtys-Grzybek, Świderska 2014; Dziawgo 2014).

The first attempt to synthesize main sources of information for corporate planning purposes in Bulgarian SMEs has been made in a study published in 2002 by a team of researchers in the field of entrepreneurship (Todorov, Kolarov, Ruychev 2002). However, the outcome of this study concentrates only on external (from the company's point of view) sources. Three indicators have been used for evaluation of the different sources, i. e. accessibility, quality and actuality ${ }^{1}$. Also, for each of these indicators a three-tier grading scale ${ }^{2}$ has been applied. The synthesis of the main external sources for information provision of company planning together with their evaluation is presented in Table 1.

Table 1. Main (external) sources for information provision of company planning

\begin{tabular}{|l|l|l|}
\hline \hline \multicolumn{1}{|c|}{ Source } & \multicolumn{1}{c|}{ Official statistics } \\
\hline \hline $\begin{array}{l}\text { Information about } \\
\ldots . .\end{array}$ & $\begin{array}{l}\text { Demographic data, Macroeconomic data, Industry data, Regional data, Data on income, } \\
\text { Data on prices, Data on consumption, etc. }\end{array}$ \\
\hline Examples & $\begin{array}{l}\text { "Statistical Yearbook", Yearbook „Population”, Yearbook "Social and Economic Develop- } \\
\text { ment", Yearbook „Employment and Unemployment”. }\end{array}$ \\
\hline Accessibility-3 & Quality-2 & Actuality - 2 \\
\hline \hline
\end{tabular}

1 The essence of the indicators defined by the above-metioned study are as follows:

- Accessibility - determined by the time and resources required for the use of the source.

- Quality - determined by the authenticity of the information and its applicability to the specific needs of the entrepreneur.

- Actuality - determined by usability at present.

2 Three-tier grading scale has the following levels:

- 1 - low;

- 2 - satisfactory;

- 3 - good. 


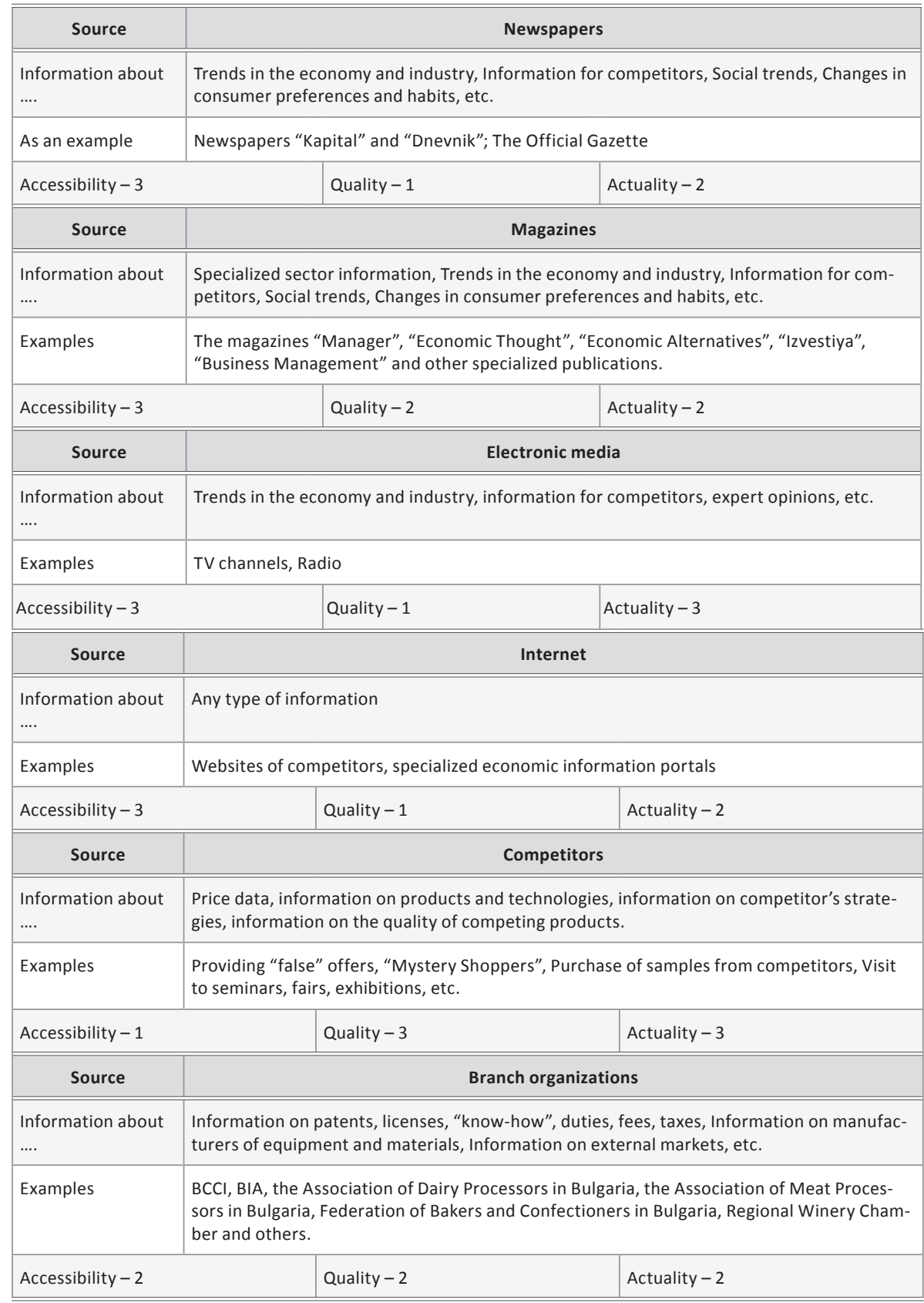




\begin{tabular}{|c|c|c|}
\hline Source & \multicolumn{2}{|c|}{ Public administration } \\
\hline $\begin{array}{l}\text { Information about } \\
\text {.... }\end{array}$ & \multicolumn{2}{|c|}{$\begin{array}{l}\text { Macroeconomic data, Data on government projects and programs, incl. public procurement, } \\
\text { economic and social trends, etc. }\end{array}$} \\
\hline Examples & \multicolumn{2}{|c|}{$\begin{array}{l}\text { Ministry of Economy, BSMEPA, Website of the Council of Ministers, Bulgarian National Bank, } \\
\text { etc. }\end{array}$} \\
\hline Accessibility -2 & Quality-3 & Actuality -2 \\
\hline Source & \multicolumn{2}{|c|}{ Branch experts } \\
\hline $\begin{array}{l}\text { Information about } \\
\text {.... }\end{array}$ & \multicolumn{2}{|c|}{$\begin{array}{l}\text { Price data, Information on products, technology, strategies of enterprises, Information on } \\
\text { the quality of products produced by various manufacturers. }\end{array}$} \\
\hline Examples & \multicolumn{2}{|l|}{ Consultants, Project partners and others. } \\
\hline Accessibility -2 & Quality-3 & Actuality -3 \\
\hline Source & \multicolumn{2}{|c|}{ Observation } \\
\hline $\begin{array}{l}\text { Information about } \\
\text {.... }\end{array}$ & \multicolumn{2}{|c|}{$\begin{array}{l}\text { Consumer data, information on competitors, information on demand for certain groups of } \\
\text { products, details of certain economic activities and more. }\end{array}$} \\
\hline Examples & \multicolumn{2}{|c|}{$\begin{array}{l}\text { Business survey in industry, construction, trade and services; business survey on investment } \\
\text { activity in industry; consumers and others. }\end{array}$} \\
\hline Accessibility -1 & Quality-3 & Actuality -3 \\
\hline Source & \multicolumn{2}{|c|}{ Own questionnaire survey } \\
\hline $\begin{array}{l}\text { Information about } \\
\text {.... }\end{array}$ & \multicolumn{2}{|c|}{ Data on consumer demand and customer preferences, propensity to buy new products, etc. } \\
\hline Examples & \multicolumn{2}{|c|}{$\begin{array}{l}\text { Business surveys of industry, construction, trade and services; investment activity in the } \\
\text { industry, the users, etc. }\end{array}$} \\
\hline Accessibility -1 & Quality-3 & Actuality -3 \\
\hline Source & \multicolumn{2}{|c|}{ Specialized software } \\
\hline $\begin{array}{l}\text { Information about } \\
\text {.... }\end{array}$ & \multicolumn{2}{|l|}{ Data for competitors, Data for suppliers, etc. } \\
\hline Example & \multicolumn{2}{|l|}{ The "Compass" Program. } \\
\hline Accessibility -2 & Quality-2 & Actuality -2 \\
\hline
\end{tabular}

S o u r c e : study based on Todorov, et al., (2002), Rykovodstvo za startirane na sobstven biznes v sferata na uslugite, Sofia, 108-110.

The above-presented table shows that the internal sources (including the enterprise accountancy with its diversity and importance for the company's planning) have been excluded from the scope of the study. For this reason, based on the results of an additional survey conducted among a representative sample of SMEs in Bulgaria in 2015, an analysis and a synthesis of basic inter- 
nal sources of information for corporate planning, related to the accountancy system of the enterprise, have been made.

To ensure continuity with the previously cited study, the new one uses the same indicators of accessibility, quality and actuality. The assessment of these indicators is made analogically with the same three-tier scale.

\section{RESEARCH METHODOLOGY}

A survey has been carried out on the basis of a pre-established organizational plan, which specifies the units, the time and the place of observation, the method of recording and reporting of data, the forms of organization, the opportunities for mistakes, etc. The sample consists of SMEs from different sectors located in the region of Ruse, North-Eastern Bulgaria. In view of the specific research, the units of observation are 49 SMEs and the period of observation is from January to October 2015. The investigated companies should have had at least three years of business experience to guarantee that they have already passed the initial stage of survival.

\section{THE OUTCOME OF THE RESEARCH PROCESS AND PROPOSALS}

The results based on the undertaken survey are summarized in Table 2. Along with the characteristics of the accountancy-based internal information sources for information provision of company planning, their degree of accessibility, quality and actuality has also been evaluated.

Table 2. Main accountancy-based sources for information provision of company planning

\begin{tabular}{|c|c|c|}
\hline Source & \multicolumn{2}{|c|}{ Synthetic and analytical accounts } \\
\hline $\begin{array}{l}\text { Information about } \\
\text { Financial resources }\end{array}$ & \multicolumn{2}{|c|}{$\begin{array}{l}\text { The information shows all receipts and payments. The cash flow for a certain period serves } \\
\text { to the liquidity planning of the enterprise and fixes the terms of payment by counterparties. } \\
\text { Financial resources include cash and cash equivalents. }\end{array}$} \\
\hline Examples & \multicolumn{2}{|c|}{$\begin{array}{l}\text { Accounts "Cash in BGN", "Cash in foreign currency", "Current accounts in BGN", "Current } \\
\text { accounts in foreign currency", "Letters of credit in national and foreign currency", "Depo- } \\
\text { sits", "Cheques", "Cash and cash equivalents", "Financial current assets", "Treasury bonds", } \\
\text { "Government securities", "Precious metals and stones". }\end{array}$} \\
\hline Accessibility - 3 & Quality - 3 & Actuality -3 \\
\hline
\end{tabular}




\begin{tabular}{|c|c|c|}
\hline Source & \multicolumn{2}{|c|}{ Synthetic and analytical accounts } \\
\hline $\begin{array}{l}\text { Information about } \\
\text { Receivables }\end{array}$ & \multicolumn{2}{|c|}{$\begin{array}{l}\text { The information about receivables is very important for making decisions for deferred reve- } \\
\text { nues and for maintaining good relationships with customers. The analysis of this information } \\
\text { is indicative of the enterprise liquidity and its policy on collection of receivables from custo- } \\
\text { mers. Receivables from customers on the instalment plan are a way to increase sales, but in } \\
\text { fact they "block" receipt of funds. As a result, a need for additional cash resources may arise, } \\
\text { the risk of uncollectible receivables increase and additional costs on receivable's collection } \\
\text { grow, etc. } \\
\text { Liquidity of a SME depends on the nature, grade and allocation of the receivables, the term } \\
\text { of their collection, etc. }\end{array}$} \\
\hline Examples & \multicolumn{2}{|c|}{$\begin{array}{l}\text { Accounts: "Receivables from customers", "Receivables from suppliers for advances", "Re- } \\
\text { ceivables on trade credits", "Receivables on sales under certain conditions", "Receivables } \\
\text { on sales with related parties", "Receivables from participating interests", "Receivables on } \\
\text { complaints", "Receivables on shortages and deficiencies", "Receivables on litigation", "Re- } \\
\text { ceivables on sentence", etc. }\end{array}$} \\
\hline Accessibility -3 & Quality-2 & Actuality -2 \\
\hline Source & \multicolumn{2}{|c|}{ Synthetic and analytical accounts } \\
\hline $\begin{array}{l}\text { Information about } \\
\text { Inventories and } \\
\text { valuables (current } \\
\text { assets) }\end{array}$ & \multicolumn{2}{|c|}{$\begin{array}{l}\text { The information is important for planning of inventories for a certain period of time and as } \\
\text { well as controlling of their consumption and storage. Thanks to this detailed information, the } \\
\text { planning of any current asset needed is possible and correct. } \\
\text { The essential point in planning is that the volume of materials has to be based on the planned } \\
\text { product mix, sales and production. The volume of current assets should allow the achieving } \\
\text { of enterprise's goals, continuity of sales and effective use of working capital. } \\
\text { The planning of inventories and valuables requires the use of natural and value indicators. }\end{array}$} \\
\hline Examples & \multicolumn{2}{|c|}{$\begin{array}{l}\text { Accounts: "Basic materials", “Additional materials", "Fuel”, "Semi-manufactured articles", } \\
\text { "Spare parts", "Stationery", "Production", "Goods", "Small productive animals", "Swarm of } \\
\text { bees", "Young animals", “Animals for fattening", etc. }\end{array}$} \\
\hline Accessibility -3 & Quality-2 & Actuality -3 \\
\hline Source & \multicolumn{2}{|c|}{ Synthetic and analytical accounts } \\
\hline $\begin{array}{l}\text { Information about } \\
\text { Fixed assets }\end{array}$ & \multicolumn{2}{|c|}{$\begin{array}{l}\text { The information shows the original cost of each fixed asset, the accumulated depreciation } \\
\text { and its net book value. Because of the ongoing depreciation, the net book value of a fixed } \\
\text { asset is always declining. Depending on the organization of the accounting, additional infor- } \\
\text { mation necessary for planning (such as the status of each asset, its technological level, etc.) } \\
\text { can also be displayed. The information about fixed assets is connected with: assessing of the } \\
\text { extent of use of available assets; determination of the need for additional investment (by } \\
\text { types) in order to achieve strategic objectives; evaluating of the investment and deprecia- } \\
\text { tion policies and their planned changes; determination of financial resources to ensure the } \\
\text { planned investments, etc. }\end{array}$} \\
\hline Examples & \multicolumn{2}{|c|}{$\begin{array}{l}\text { Accounts: "Land", "Forests", "Perennial plants - fruit-bearing", "Perennial plants - non fru- } \\
\text { it-bearing", "Draught animals", "Buildings and structures", "Machinery and equipment", } \\
\text { "Transport vehicles", "Office furnishing", "Equipment", "Computer equipment", "Other tan- } \\
\text { gible fixed assets", "R\&D Products", "Intellectual Property Rights", "Software", "Industrial } \\
\text { property rights", etc. }\end{array}$} \\
\hline Accessibility - 3 & Quality-3 & Actuality -3 \\
\hline Source & \multicolumn{2}{|c|}{ Synthetic and analytical accounts } \\
\hline $\begin{array}{l}\text { Information about } \\
\text { Liabilities }\end{array}$ & \multicolumn{2}{|c|}{$\begin{array}{l}\text { The information for liabilities shows their type and characteristics; who is the supplier; what } \\
\text { is the deferral in payment, etc. The analysis of this information is an indicator for liquidity and } \\
\text { indebtedness of the enterprise, as well as for its net working capital. }\end{array}$} \\
\hline
\end{tabular}




\begin{tabular}{|c|c|c|}
\hline Examples & \multicolumn{2}{|c|}{$\begin{array}{l}\text { Accounts: "Customers on advance payment", "Liabilities to suppliers", "Liabilities to suppliers } \\
\text { on trade credits", "Liabilities to suppliers under certain conditions", "Liabilities to suppliers } \\
\text { with related parties", "Liabilities to the staff", "Liabilities for unused annual leave", "Liabili- } \\
\text { ties to participating interests", "Liabilities to the municipality", "Liabilities for income tax", } \\
\text { "VAT Liabilities", "Liabilities for taxes on income of individuals", "Liabilities to ministries", } \\
\text { "Liabilities for excise", "Liabilities to Customs", "Liabilities to NSSI", "Liabilities under the vo- } \\
\text { luntary social insurance", "Liabilities for health insurance", "Liabilities for one-time aid and } \\
\text { family allowance", "Liabilities to international financial institutions", "Liabilities to creditors". }\end{array}$} \\
\hline Accessibility -3 & Quality-3 & Actuality -3 \\
\hline Source & \multicolumn{2}{|c|}{ Synthetic and analytical accounts } \\
\hline $\begin{array}{l}\text { Information about } \\
\text { Expenditure }\end{array}$ & \multicolumn{2}{|c|}{$\begin{array}{l}\text { The information about expenditures is directly related to decision-making in SMEs. Planned } \\
\text { amount of costs has to be determined on the base of respective statements on individual } \\
\text { items of expenditure - this is a planning requirement. In the coming periods, thus determine } \\
\text { more precisely the expenditures changes, disclose and indicate possibilities and ways for } \\
\text { their reduction and achieving relative savings for the enterprise. } \\
\text { An important indicator for the SMEs is the cost effectiveness. It gives the opportunity to } \\
\text { compare companies on sector and sub-sector level and to plan strategic moves. }\end{array}$} \\
\hline Examples & \multicolumn{2}{|c|}{$\begin{array}{l}\text { Accounts: "Material expenditure", "External service expenditure", "Depreciation", "Sala- } \\
\text { ries", "Social costs", "Taxes and similar payments", "Expenditure for provisions", "Expen- } \\
\text { diture from the revaluation of assets", "Other expenditure", "Operating costs", "Costs for } \\
\text { supporting activities", "Costs for acquisition of fixed assets", "Administrative costs", "Cost of } \\
\text { Sales", "Liquidation costs of fixed assets", "Interest", "Operations with financial assets and } \\
\text { instruments", "Expenses on foreign currency transactions", "Impairment expenses", "Non-fi- } \\
\text { nancial expenses for future periods", "Financial expenses for future periods", "Extraordinary } \\
\text { expenses". }\end{array}$} \\
\hline \multicolumn{2}{|l|}{ Accessibility -3} & Actuality -3 \\
\hline Source & \multicolumn{2}{|c|}{ Synthetic and analytical accounts } \\
\hline $\begin{array}{l}\text { Information about } \\
\text { Revenue }\end{array}$ & \multicolumn{2}{|c|}{$\begin{array}{l}\text { It is important for the information for revenues of SMEs to be structured by products (servi- } \\
\text { ces) and business activities. Essential is that the net sales revenue have to be in accordance } \\
\text { with the chosen business strategy. } \\
\text { For a SME, an important indicator is the effectiveness of revenue, which is an alternative } \\
\text { indicator of the cost effectiveness. The index is also suitable for comparisons on sectoral and } \\
\text { sub-sector level and for planning of future strategic moves. }\end{array}$} \\
\hline Examples & \multicolumn{2}{|c|}{$\begin{array}{l}\text { Accounts: "Revenues from sales of products", "Revenues from sales of goods", "Revenues } \\
\text { from sales of services", "Financing", "Revenues from sales of fixed assets", "Revenues from } \\
\text { sales of materials", "Other revenues", "Interest income", "Income from participating intere- } \\
\text { sts", "Income from operations with financial assets and instruments", "Income on foreign } \\
\text { currency transactions", "Income from revaluation of financial assets and instruments", "In- } \\
\text { come from impairment losses reversed", "Extraordinary". }\end{array}$} \\
\hline Accessibility -3 & Quality-3 & Actuality - 3 \\
\hline
\end{tabular}

S o u r c e : own study, 2015.

On the basis of the synthesis of the accountancy-based sources, a generalization concerning the role of accountancy-based information in the planning process of SMEs can be outlined:

- Accountancy-based sources can contribute essentially to the assessment of a situation when reliable internal and external data is needed. 
- Accountancy-based sources possess a high level of flexibility needed for different financial analyses.

- Accountancy-based sources ensure a quick reaction to timely plan income, expenses, investments and funding.

- Accountancy-based sources guarantee a non-error work and does not require frequent adjustments in the estimates of income and expenditure and the formed financial result.

- Accountancy-based sources constitute an irreplaceable instrument for preparing of good plans and their successive implementation.

There is also a room for concrete proposals concerning the adapting of information for planning purposes in SMEs. As examples the following two can be resumed:

- Stemming from the movements in the accounts reflecting receivables, a scheme for cash inflows by months can be set up.

- Based on movements in the accounts reflecting liabilities to suppliers, a scheme for the cash outflows by months can be formed.

\section{THE CONCLUSIONS FROM THE RESEARCH}

A rapidly changing environment makes it difficult to determine, which sources support mostly planning activities in SMEs. A systematization of the main information sources contributes essentially to the good quality of plans and affects the efficient running of the whole planning process.

Accountancy represents a system for measuring the activity of an enterprise with view of providing a variety of information. Some authors (Drury 2005; Bramford and Bruton 2006; Pyka 2015) define accountancy primarily as a means for internal (with the management) and external (with the stakeholders) communication of an enterprise. From the systematization of the sources of accountancy information and their evaluation, offered in this study, it becomes clear that due to their relatively high level of quality, actuality and availability, the accountancy-based data can constitute a major source of information for planning purposes in SMEs. 


\section{REFERENCES}

Bramford, C., \& Bruton, G. (2006). A framework for success: Small business management. United States of America: Thomson South-Western.

Ciemleja, G., \& Lāce, N. (2009). SME Performance Management Using Life Cycle Stage Concept. In: Мировая экономика и бизнес-администрирование: $5^{-я}$ международная научно-практическая конференция, Belarus, Minsk, 28-30 May, 2009. Minsk: BNTU, 119-127.

Drury, C. (2005). Management and cost accounting. $6^{\text {th }}$ ed. London: Thomson SouthWestern.

Dziawgo, L. (2014). Greening financial market. Copernican Journal of Finance \& Accounting 3 (2), 9-23. http://dx.doi.org/10.12775/CJFA.2014.014.

Germanos, G, Pliota, T., \& Germanou, E. (2013). A qualitative approach of strategy formulation of Greek Small-Medium (SME) companies in times of crisis from an accounting perspective. In: Proceedings of the 3rd International Conference: Quantitative and Qualitative Methodologies in the Economic \& Administrative Sciences, Greece, Athens, 23-24 May, 2013, 192-202.

Kocmanová, A., \& Simberova, I. (2014). Determination of environmental, social and corporate governance indicators: framework in the measurement of sustainable performance. Journal of Business Economics and Management 15 (5).

Papazov, E. (2014). A "Reverse" Approach to Coordination of Strategic and Tactical Financial Decisions for Small Business Growth. Procedia - Social and Behavioural Sciences, 156, 161-165.

Papazov, E., \& Mihaylova, L. (2010). Information provision for strategic planning in Bulgarian SMEs. Review of international comparative management, 11 (4), 575-581.

Papazov, E., \& Mihaylova, L. (2014). Linking Accounting Information with Business Planning in Bulgarian SMEs. Paper presented at the $8^{\text {th }}$ International Management Conference: Management challenges for sustainable development. Bucharest, Romania, 321-327.

Peršić, M., Bakija, K., \& Vlašić, D. (2015). Framework for improving quality and comparability of non-financial reporting system. Copernican Journal of Finance \& Accounting 4 (2), 109-127. http://dx.doi.org/10.12775/CJFA.2015.019.

Pyka, I. (2015). Balance sheet policy of central banks in the conditions of the exit strategy of central banks. Journal of Economics and Management - University of Economics in Katowice 21 (3), 110-127.

Raulinajtys-Grzybek, M., \& Świderska, G. (2014). Object-based costing as an important tool for the economic analysis of sustainable development. Copernican Journal of Finance \& Accounting 3 (1), 135-144.

Simeonov, O., \& Lambovska, M. (2012). A suggestion about potentialities for the SWOT analysis's development concerning threats. Ekonomika a management / E+M Economics \& Management, (2), 94-103.

Todorov, K., Kolarov, K., \& Ruychev, S. (2002). Rykovodstvo za startirane na sobstven biznes v sferata na uslugite, Sofia, Bulgaria, 108-110 (in Bulgarian). 